\title{
THE UTILIZATION OF VEGETABLE AND FRUIT WASTES FOR SACCHAROMYCES CEREVISIEAE CELL WALL BASED SS-GLUCAN PRODUCTION WITH ANTIOXIDANT ACTIVITY
}

\author{
Gemilang Lara Utama ${ }^{1}$, Florensia Irena ${ }^{1}$, Elazmanawati Lembong ${ }^{1}$, \\ Indira Lanti Kayaputri ${ }^{1}$, Tensiska Tensiska ${ }^{1}$, Roostita Lobo Balia ${ }^{2}$
}

\footnotetext{
${ }^{1}$ Faculty of Agro-Industrial Technology, Universitas Padjadjaran, Jl. Raya Bandung Sumedang Km.21, 40600, Sumedang, Indonesia

${ }^{2}$ Faculty Animal Husbandry, Universitas Padjadjaran, Jl. Raya Bandung Sumedang Km.21, 40600, Sumedang, Indonesia
}

Link to this article: https://doi.org/10.11118/actaun202068010119

Received: 26. 10. 2019, Accepted: 7. 1. 2020

To cite this article: UTAMA GEMILANG LARA, IRENA FLORENSIA, LEMBONG ELAZMANAWATI, KAYAPUTRI INDIRA LANTI, TENSISKA TENSISKA, BALIA ROOSTITA LOBO. 2020. The Utilization of Vegetable and Fruit Wastes for Saccharomyces cerevisieae Cell Wall Based §s-Glucan Production with Antioxidant Activity. Acta Universitatis Agriculturae et Silviculturae Mendelianae Brunensis, 68(1): 119-127.

\begin{abstract}
The study aims to determine the number of mass and antioxidant activity of ßs-glucan extracted from S.cerevisieae which grown on vegetable and fruit wastes. The method used is experimental with descriptive analysis which consisted of 3 treatments namely banana waste, papaya waste, and napa cabbage waste as fermentation medium, repeated thrice. Fermentation medium was made by mixing waste with water with the ratio of 1:2. Ten percent (w/v) of S.cerevisieae was inoculated and incubated for 48 hours, at $27^{\circ} \mathrm{C}$. Extraction of §-glucan was carried out using acid-alkaline methods and antioxidant activity was tested by DPPH (2, 2-Dyphenyl-1-Picrylhydrayl) method and the microstructure of $§$-glucan is determined by Scanning Electrone Microscope. The result showed that the best medium in producing §-glucan was papaya waste which resulting $19.094 \mathrm{~g}$ ß -glucan mass, with radical scavenging activity of $20.71 \%$ and globular diameter of $533 \mu \mathrm{m}$.
\end{abstract}

Keywords: antioxidant activity, S-glucan, banana waste, napa cabbage waste, papaya waste

\section{INTRODUCTION}

Organic waste amounts up to $60 \%$ of total waste in Indonesia. According to the Directorate of Waste Management, total wastes in Indonesia are estimated to be 175,000 ton a day or 64 million ton per year (Yodha, 2018). This considerable amount of organic waste becomes one of the problems that is sufficiently disestablished by the government. In addition to causing unpleasant smell, organic waste can also cause disease and pollution.

In anaerobic condition, organic waste can decompose into $\mathrm{CO}_{2}$ gas and $\mathrm{CH}_{4}$ gas. These gases are categorized as gases that can damage the ozone layer (Rachmawati and Herumurti, 2015). Further, the destruction of ozone layer causes the ultraviolet rays, which are free radicals, to be able to expose earth directly.

Various kind of innovations to prevent free radicals are widely practiced. One of them uses a compound known as antioxidant. Some examples of antioxidant compound are phenolic acids, anthocyanins, and ascorbic acid, which are are often found in functional food (Xu, 2012). In addition to these compound, there are other compounds that function as antioxidant, one of them is §-glucan, which is not widely known by the public. S-glucan has several advantages such 
as the ability to easily absorb by the body (El Khoury et al., 2012). Furthermore, other biological activity of $\beta$-glucan is that it is able to act as antioxidant, antitumor, anti cholesterol, and potentially increase the immune system (Bashir and Choi, 2017; Rahar et al., 2011; Vetvicka et al., 2019).

One source of $\lesssim$-glucan is the cell wall of microorganism. One of microorganisms that have the potential strains producing $§$ glucan is Saccharomyces cerevisiae which is non - pathogenic and non - toxic, therefore these microorganisms are often used for fermentation of food products(Pengkumsri et al., 2017). ß-glucan and S. cerevisiae are categorized as Generally Recognized As Safe (GRAS) by the FDA (Food and Drug Administration), meaning that it has no toxicity or side effects (Leentjens et al., 2014). S-glucan contained in the $S$. cerevisiae's cell wall and has the potential also safe to be a food additive (Aimanianda et al., 2009). S. cerevisiae cell wall establish 15 to $30 \%$ of the dry weight of the cell, then the more population of S.cerevisiae grown the more §s-glucan is produced (Lesage and Bussey, 2006).

S. cerevisiae can be cultivated through fermentation with using high carbohydrate substrate. One of the high carbohydrate substrate and not yet widely used is vegetable and fruit waste. In addition to high carbohydrates, the availability of vegetable and fruit waste in Indonesia is very large (Utama et al., 2019). Three kinds of vegetable and fruit waste that have the highest amount and from year to year keeps increasing are banana waste, papaya waste, and napa cabbage waste (Central Bureau of Statistics, 2015).

Based on that, the napa cabbage waste, banana waste, and papaya waste can be used as an alternative fermentation medium of S.cerevisiae to produce $\S$-glucan. However, the biological potential of §s-glucan such as antioxidant should be determined. This research was conducted to determine the antioxidant activity of §s-glucan and to know which kind of waste that can be utilized as the best fermentation medium.

\section{MATERIALS AND METHODS}

\section{S. cereviseae Growth}

Commercial S. cerevisiae from Fermipan used in this research. One gram of $S$. cerevisiae was taken then mixed into $9 \mathrm{ml}$ Yeast Glucose (YG) broth and incubated for 72 hours at $27^{\circ} \mathrm{C}$. The cell concentration of S.cereviseae were determined every 24 hours by measuring optical density at wavelength $600 \mathrm{~nm}$ using a UV-VIS 9200 spectrophotometer (Balia et al., 2018).

\section{Preparation of Fermentation Medium}

Fermentation medium was made by firstly sorting the napa cabbage, banana, and papaya waste that will be used as the fermentation medium. The sorted wastes were then cutted and blendered. The ratio of waste mixed with the 10\% sugar solution is $1: 2$ $(\mathrm{w} / \mathrm{v})$. The semi-solid waste was heated at $75^{\circ} \mathrm{C}$ for
15 minutes and cooled until room temperature (27$28^{\circ} \mathrm{C}$ ). $10 \%$ (w/v) of S. cerevisiae from Fermipan was inoculated and incubated for 48 hours (Modification of Gunam et al., 2011).

\section{Extraction of §-glucan}

The yeast cells were collected via centrifugation of fermentation medium for 10 minutes at 7,500 rpm. The pellets were collected and weighed as mass of cells. Furthermore 15\% (w/v) of the cell mass was immersed in pH 5.0 distillation conditioned on a $1.0 \mathrm{M} \mathrm{HCl}$ solution and incubated at $50{ }^{\circ} \mathrm{C}$ for 48 hours. Cell autolysis was performed by incubating sample for 15 minutes at $80^{\circ} \mathrm{C}$. After incubation, yeast cells were collected by centrifugation for 10 minutes at 5,000 rpm. The obtained pellets were dried at $60{ }^{\circ} \mathrm{C}$ until extraction. The pellet was washed with $1.0 \mathrm{M} \mathrm{NaOH}$ and mixed for 2 hours at $80^{\circ} \mathrm{C}$. The autolyzed cells were recovered by centrifugation for 25 minutes at $7.500 \mathrm{rpm}$. The obtained pellet was washed with $1.0 \mathrm{M} \mathrm{CH}_{3} \mathrm{COOH}$ and mixed for 2 hours at $80^{\circ} \mathrm{C}$. Pellet is recovered by centrifugation for 25 minutes at $7.500 \mathrm{rpm}$. The resulting pellet was dried with by freeze drying at $-50{ }^{\circ} \mathrm{C}$ and weighed into ßs-glucan mass (Pengkumsri, 2016).

\section{Determintation of Antioxidant Activity}

S-glucan and the fermentation medium of each waste are each made into test solutions by extraction using methanol to have a certain concentration as a stock solution. The extraction was done by adding methanol and mixing it for 30 minutes. The mixing results are filtered and fixed on the measuring flask. Each of the test solution was prepared by making series of $2 \mathrm{ml}, 1 \mathrm{ml}, 0.5 \mathrm{ml}, 0.25 \mathrm{ml}$, and $0.125 \mathrm{ml}$ of each test solution and adjusted by methanol to the total volume of $2 \mathrm{ml}$. Antioxidant activity were determined by adding $0.5 \mathrm{ml}$ of $160 \mathrm{ppm} \mathrm{DPPH}$ solution to each series. The series of tests were incubated for 30 minutes and then their absorbance was measured by spectrophotometer at $517 \mathrm{~nm}$ wavelength. The obtained absorbance was used to calculate the percentage of inhibition (Mu'nisa, 2012)

$\%$ Inhibition $=$

$=\frac{\text { Blank Absobance }- \text { Sample Absorbance }}{\text { Blank Absorbance }} \times 100 \%$.

\section{Characterization of $\beta$-Glucan Microstructure}

ßs-glucan was prepared by coating with Palladium Allu and affixed carbon tape to the specimen mount. Then adjusted to the sample surface height and height of the specimen holder surface. Next the sample is tightened with the appropriate coupler. The visualization and photography of the samples were performed using a Jeol JSM - 6360LA Electron microscope at an acceleration voltage of $10 \mathrm{Kv}$ (Novák et al., 2012). 


\section{RESULTS AND DISCUSSION}

\section{The Growth of S. cereviseae}

S. cerevisiae growth curve can be seen in Fig. 1. This growth curve is obtained based on the optical density. Fermentation time of 0-24 hours showed an increasing graph with absorbance of 0.302 to 0.393. Fermentation time of 24-48 hours, showed a rapid increase and the highest value is obtained at 48 hours with an absorbance value of 0.489. Decreasing growth of $S$. cerevisiae occurred after 48 hours of fermentation, where at 72 hours fermentation the absorbance value decreased to 0.176 . This absorbance value represents the number of $S$. cerevisiae cells, the higher absorbance value the higher number of S. cerevisiae cells obtained (Salari and Salari, 2017). Fig. 1 showed the fermentation time from 0-24 hours for S. cerevisiae which has the lowest growth rate, where this phase is adaptation phase or lag phase where S. cerevisiae were still adapting to the growth environment (Vermeersch et al., 2019).

At 24 to 48 hours, there was an increase in growth rate. This phase is called the exponential growth phase or logarithmic phase. In this phase S. cerevisiae reached the peak of growth at 48 hours of fermentation medium. The logarithmic phase occured at 48 hours because at that time $S$. cerevisiae has adapted to the medium environment so that the nutrients of the fermentation medium can be used optimally and S. cerevisiae can divide quickly and constantly (Castilleja et al., 2017). In addition, at 48 hours of fermentation, S. cerevisiae has produced primary metabolites in the form of organic acids which can affect the $\mathrm{pH}$ of the medium to be optimal for growth (Stewart, 2017). After 48 hours, $S$. cerevisiae decreased due to entering the death phase. In this phase, there is a reduction in the number of microorganisms due to production of primary metabolites which are toxic to S. cerevisiae (Sanchez and Demain, 2008).

The logarithmic phase is the optimum phase in producing $\S$-glucan, because at this phase the amount of S. cerevisiae's cells reached its highest, thus the amounts of §s-glucan also reached maximum (Willaert, 2019). Based on Fig. 1, the logarithmic phase occurred at 48 hours of fermentation, therefore this fermentation time was used as the optimal time for the production of ßs-glucans from S. cerevisiae by using various vegetable and fruit waste as fermenentation medium (banana waste, papaya waste, and napa cabbage waste).

Fermentation medium has an important role in the mass multiplication process of S. cerevisiae cells (Mohd Azhar et al., 2017). S. cerevisiae requires elements such as $\mathrm{C}, \mathrm{H}, \mathrm{O}, \mathrm{N}, \mathrm{P}$, and micro elements such as Fe, $\mathrm{Cu}$, and $\mathrm{Mg}$ (Walker and Stewart, 2016). These elements are often obtained in the form of carbohydrates, proteins and minerals. S. cerevisiae requires elements of nitrogen obtained from fermentation medium in the form of amino acids and peptides which can be a support in growth metabolism. This nitrogen will be used by $S$. cerevisiae in the process of cell wall formation by affecting the constituent chain of cell walls (Orlean, 2012). The mineral component required for $S$. cerevisiae are magnesium, sodium, calcium, iron, zinc, and others (Eide et al., 2005). These metal ions are used by $S$. cerevisiae to optimize the fermentation process and help the biosynthesis of nucleic acids, phospholipids, and ATP (energy) income (Walker and Stewart, 2016).

The main nutrients in the form of carbohydrates that are often found in the form of sugar are important nutrients in the S.cerevisiae fermentation process. Sugar is one of the main component that act as energy producers which found in the form of glucose, sucrose, maltose, cellulose, hemicellulose, lactose, and fructose (Kechkar et al., 2019). The sugar component other than glucose will firstly be converted to glucose in the presence of enzyme, such as invertase and zimase, from S. cerevisiae (Ostergaard et al., 2000). Thus, the higher the carbohydrate content, the higher nutrients available thus the higher growth of S. cerevisiae (Broach, 2012).

\section{The Production of $§$-Glucan with the Utilization of Vegetable and Fruit Wastes}

The results of cell mass and the mass of §-glucan from S. cerevisiae cultivated in different fermentation medium such as banana waste, papaya waste, and napa cabbage waste can be



1: The Growth Curve of S. cerevisiae 
seen in Fig. 2. Based on Fig. 2, it is known that fermentation using banana waste as medium resulted as many as $144.399 \mathrm{~g}$ of cell mass and 21.619 grams of $§$-glucan mass. Papaya waste fermentation medium produced $139.518 \mathrm{~g}$ of cell mass and 19.094 grams of $§$-glucan mass, and napa cabbage waste medium produced $74.810 \mathrm{~g}$ of cell mass and $9.802 \mathrm{~g}$ of $\mathrm{S}$-glucan mass. The highest amount of $S$. cerevisiae cell mass is produced by using fermentation medium from banana waste. This could be caused by the nutritional content of banana waste, which has the highest carbohydrate content compared to fermentation medium made by papaya waste and napa cabbage waste (Pyar and Peh, 2018).

The mass of $S$. cerevisiae cells from papaya waste as fermentation medium is higher than napa cabbage waste as fermentation medium, but lower than banana waste as fermentation medium. This situation can occur because the number of carbohydrate from papaya waste is lower than banana waste but higher than napa cabbage waste, thus the resulting cell mass yield is lower than the cell mass from banana waste fermentation medium but higher than the amount of cell mas from napa cabbage fermentation medium (Pyar and Peh, 2018; Saran et al., 2016; You et al., 2017).

The cell mass was obtained by cell autolysis or breakdown of cells to obtain §s-glucans (Piotrowska and Masek, 2015). The \$s-glucan mass will be in line to the mass of the cell produced. This occured because $\S$-glucan is obtained from the cell wall, the number of cells will determine the amount of §-glucan produced (Aimanianda et al., 2009). Components that play an important role in the formation of $\beta$-glucan are also glucose. Therefore, the highest $\S$-glucan mass is produced by using banana waste fermentation medium because the highest glucose content is found in banana waste so that it can maximize the $S$-glucan production process (Pengkumsri et al., 2017; Pyar and Peh, 2018). The metabolism of the formation of §-glucan is in the presence of glucose which is converted to glucose-6-phosphate wherein the presence of the enzyme phosphoglucomutase is obtained by glucose-1-phosphate and is broken down into UDPGlucose which is the constituent component of the cell wall of S. cerevisiae (Orlean, 2012).

The mass of $\S$-glucan and cell mass can be used to find the percentage of $S$-glucan produced based on the cell mass obtained. The highest percentage of §s-glucan produced was obtained from banana waste which was $14.972 \%$, followed by the mass of $९$-glucan from the papaya waste as fermentation medium with $13.686 \%$, and the mass of $\beta$-glucan with napa cabbage waste as fermentation medium as much as $13.102 \%$. In general, the percentage of §-glucan to cell mass obtained from S. cerevisiae is 9-11\% in standard medium (Piotrowska and Masek, 2015). The results show higher percentage of §-glucan obtained from fermentation medium with vegetable and fruit waste supplementation.

This percentage represents the total percentage of ß-glucans. Details of the percentage of the $\S$-glucan types from the $S$. cerevisiae cell wall were $50-55 \%$ in the form of $(1,3)$ Ss-D-glucan, $5-10 \%$ in the form of $(1,6)$ S-D-glucan, and 3-7\% in the form of $(1,4)$ a $(1,3)$ is-D-glucan (Aimanianda et al., 2009; Klis et al., 2002; Ruiz-Herrera and Ortiz-Castellanos, 2019). The dominating type of §-glucan bond from $S$. cerevisiae is a special feature of the ßs-glucan produced. This $\$$-glucan type $(1,3)$ S-D-glucan has a higher biological activity compared to other types of S-glucans (Bashir and Choi, 2017). This is due to the small molecular mass $(1,3)$ §-D-glucan, where the smaller molecular mass allows higher biological activity is produced (Rahar et al., 2011).

\section{Antioxidant Activity of ß-glucan from $S$. cereviseae with Vegetable and Fruit Wastes as Fermentation Medium}

Antioxidant activity of waste and $\varsigma$-glucan extract can be seen in Fig. 3. Antioxidant activity of banana waste fermentation medium was obtained

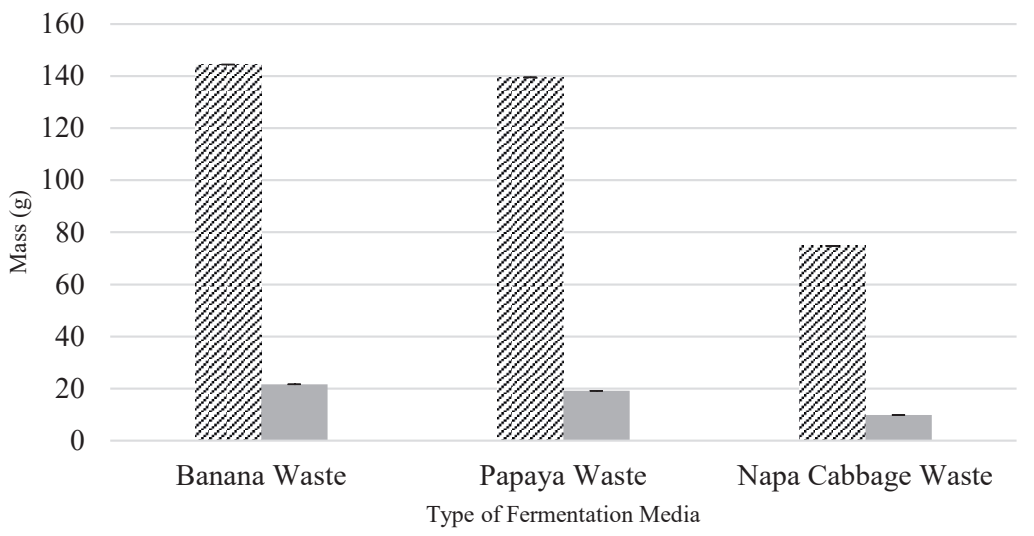

: Cell Mass Mass of Beta Glucan

2: $\beta$-glucan Production with Vegetable and Fruit Wastes 


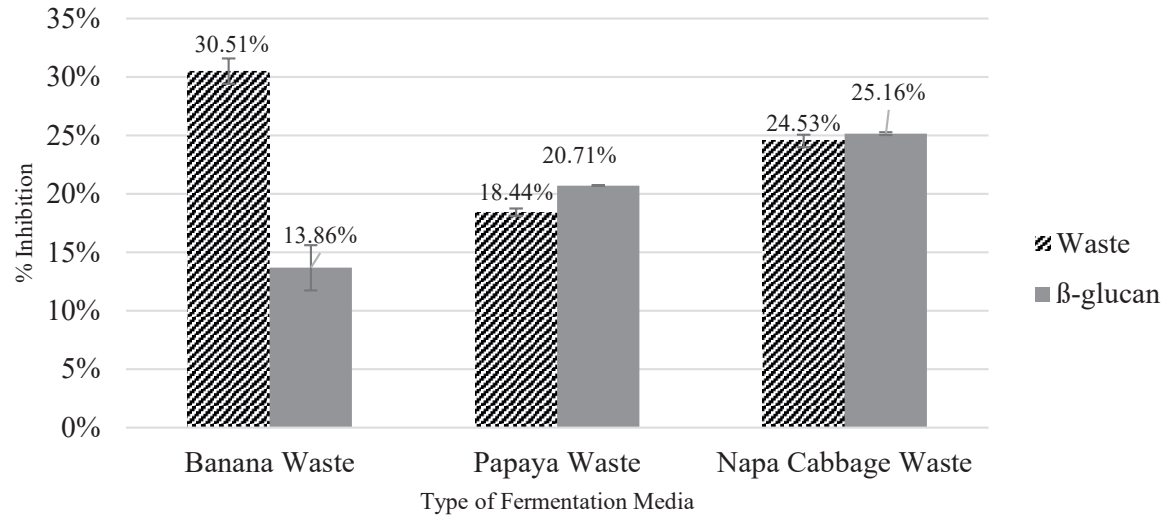

3: Antioxidant Activity from Various Wastes and Extracted $\beta$-glucan

by $30.51 \%$ and the antioxidant activity of $\S$-glucan using banana waste as fermentation medium was obtained by $13.68 \%$. Fermentation medium of papaya waste was $18.44 \%$ while antioxidant activity of $§$-glucan from the fermentation medium was $20.71 \%$. The results of antioxidant activity on napa cabbage waste as fermentation medium were $24.53 \%$ and $25.16 \%$ from 3 -glucan produced.

In general, the antioxidant activity of $\beta$-glucan derived from yeast has 10\% of inhibition (Kofuji et al., 2012). Based on the results, ßs-glucan antioxidant activity obtained higher activity compared to the activity of $\beta$-glucan from yeast in general, this can occur because the ßs-glucan obtained is possible not only from $S$. cerevisiae but also with s-glucan from fermented medium which is extracted (Taurisano et al., 2014).

The results of the comparison of antioxidants from wastes with §-glucans has different activity in each type of waste. The antioxidant activity of banana waste is higher than the activity of §-glucan antioxidant extracted by banana waste fermentation medium, but when viewed from the large decrease in antioxidant activity of each concentration, antioxidant activity in banana waste has a high difference. It can be concluded that the antioxidant activity of banana waste is indeed higher but less stable when compared with the antioxidant activity of s-glucan extracted by the fermentation medium of banana waste, which had a lower antioxidant activity but a more stable decrease. Compounds that play an important role as antioxidants in banana waste are flavonoids, which does have a less stable structure (Bhatt and Patel, 2015; Sidhu and Zafar, 2018). The antioxidant activity of banana waste is also possible from amino acids, peptides, flavonoid compounds, catecholamines, dopamine, dopamine polymers, and it is possible that the $\S$-glucan component is counted as an antioxidant activity from banana waste (Torres-León et al., 2018; Varzakas et al., 2016).

Antioxidant activity of $\S$-glucan extraction results was higher than the antioxidant activity of papaya waste. This happened because ßs-glucan were extracted so produced higher biological activity (Wang et al., 2017). The main antioxidant component of papaya waste itself is polyphenol (Verghese et al., 2016). Polyphenol has a high sensitivity level so it is possible that it was damaged during process (Gunathilake et al., 2018).

The antioxidant activity of Ss-glucan extracted from the medium of napa cabbage waste fermentation has more antioxidant activity compared to the antioxidant activity of the napa cabbage waste itself. This can occur because the antioxidant component of napa cabbage waste is $ß$-carotene and vitamin $\mathrm{C}$ which is less stable, thus resulted in low antioxidant activity (Anwar et al., 2018). It could also due to the S-glucan found in napa cabbage waste does not work optimally because it was still in crude form. Meanwhile the antioxidant activity of s-glucan produced by the medium of napa cabbage waste fermentation can produce higher results because the S-glucan is purer due to the extraction process.

The antioxidant activity of $\S$-glucan from each fermentation medium also showed different values. This difference in antioxidant activity could occur due to the different characteristics of each ßs-glucan extracted. The difference of the components contained in the fermentation medium will affect the fermentation process, especially in terms of the formation of cell wall components, therefore the biological activity of §-glucan produced are different (Rahar et al., 2011; Varelas et al., 2017). The main components that influence cell wall formation are carbon and nitrogen, which are often found in the form of carbohydrates and proteins (Ogden et al., 2018).

According to (Wu et al., 2008), the best percentage of carbon and nitrogen elements in producing Ss-glucan seen from its functional ability is $4 \%$ carbon with $2.5 \%$ nitrogen which is similar with napa cabbage waste resulting in a higher functional ability compared to banana and papaya waste which both have different content of carbon and nitrogen. In addition, with the highest amount of nitrogen found in napa cabbage waste, the formation of §-glucan with short branch chains 
such ad $§$ - (1,3) -D-glucan and $§$ - (1,6) -D-glucan, can be more optimum (Aimanianda et al., 2009; Yoshimi et al., 2017). The formation of this short branch chain affects the physical properties of the resulting particle size which will be smaller than the particle size of the long linear chain (Nickels et al., 2016).

The different size of $\S$-glucan particles will also cause different antioxidant activity of ss-glucan. There is an inverse proportion between antioxidant activity and particle size.The smaller particle size the higher antioxidant activity of $s$-glucan (Kurek et al., 2016). The small size of §-glucan having also a small molecular mass, will enable it to dissolve more readily thus making the antioxidant higher (Wang et al., 2017).

These results are supported by the 今-glucan microstructure which can be seen in Fig. 4.
At 30× magnification, the size of $\S$-glucan particles from each fermentation medium was obtained at $700 \mu \mathrm{m}$ from the banana waste fermentation medium, $500 \mu \mathrm{m}$ from the fermentation medium for papaya waste, and $300 \mu \mathrm{m}$ from the napa cabbage waste fermentation medium, while for globular of s-glucan obtained different magnifications from each fermentation medium. Globular S-glucan with banana waste fermentation medium has a diameter of $825 \mu \mathrm{m}$ measured at 100× magnification. §-glucan with papaya waste fermentation medium also has a diameter of $533 \mu \mathrm{m}$ using 150× magnification. ß-glucan with napa cabbage waste fermentation medium obtained globular with $370 \mu$ m diameter at 250× magnification.

These results showed that the diameter of ß-glucan from each fermentation medium have different size, while commercial globular §s-glucans

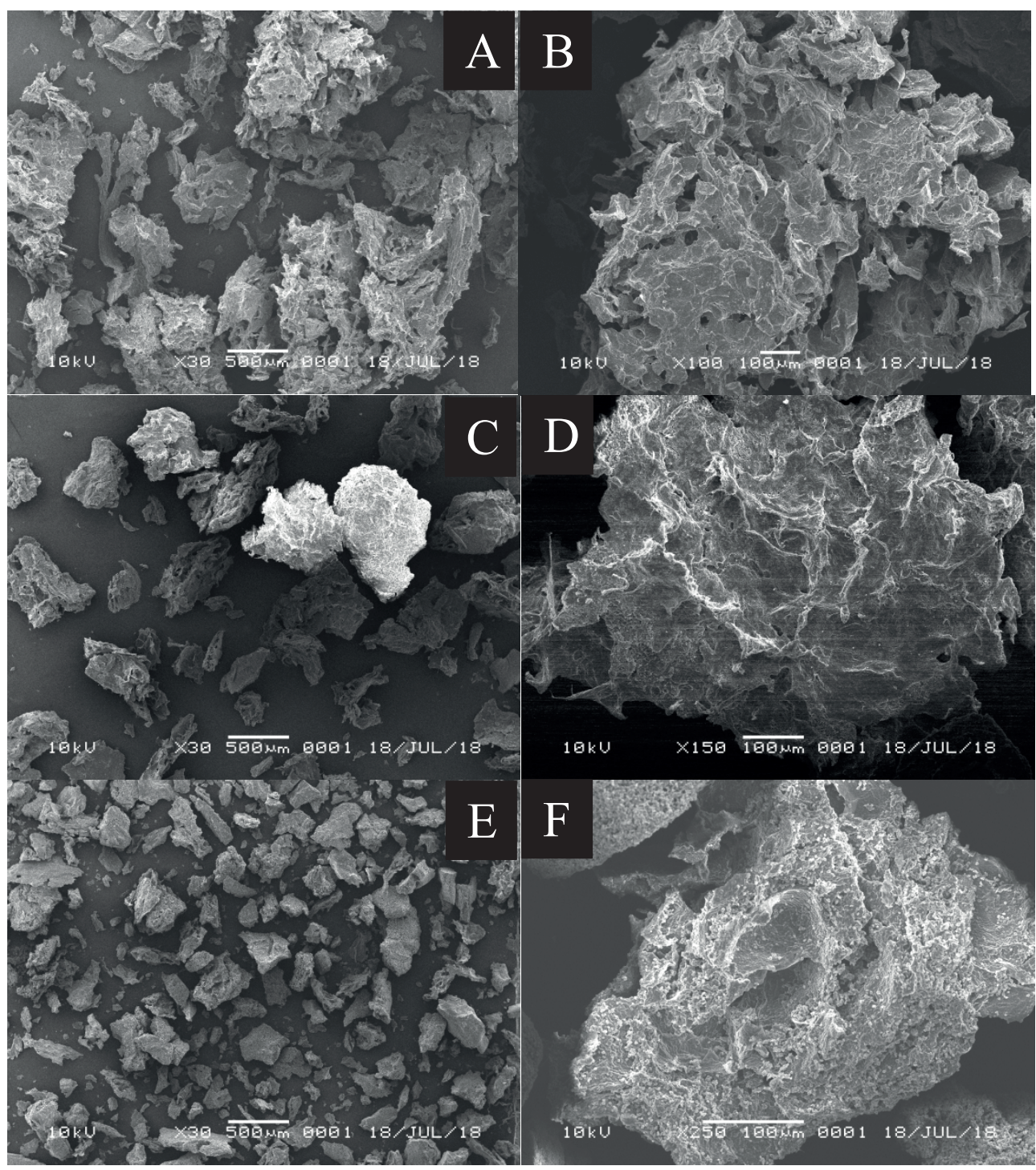

4: The microstructure of $\beta$-glucan produced by banana waste fermentation medium ( $A$ and B), $\beta$-glucan produced by papaya waste fermentation medium ( $C$ and $D$ ), and $\beta$-glucan produced by napa cabbage fermentation medium ( $E$ and $F$ ) 
have diameter from $5 \mu \mathrm{m}$ to $100 \mu \mathrm{m}$. This occurred due to differences in the substrate used to produce 今-glucans and its purity (Piotrowska and Masek, 2015). ßs-glucan microstructure with fermentation medium of napa cabbage waste has the smallest microstructure size, meaning it has the highest solubility thus resulted in the highest antioxidant activity (Wang et al., 2017). Meanwhile ßs-glucan derived from papaya waste medium has a greater size than napa cabbage's but smaller size than banana's. Napa cabbage waste resulting the lower antioxidant activity than s-glucan with napa cabbage waste fermentation medium but higher than the antioxidant activity of S-glucan with banana waste fermentation medium. §-glucan from banana waste fermentation medium has the largest microstructure size and lowest solubility therefore the lowest antioxidant activity produced.

Based on visual observation, each §-glucan has similar globural shape, but when viewed extensively the shape of each $§$-glucan particles has different size. The different carbon and nitrogen content in banana waste, papaya waste, and napa cabbage waste affect the of cell wall's size, especially the formation of S-glucans (Wu et al., 2008). The higher availability of carbon and nitrogen in the fermentation medium used, the greater $\$$-glucan's particle size produced (Upadhyay et al., 2017).

Largest $\$$-glucan particle size is obtained from the fermentation medium of banana waste which has the highest carbon content with the lowest nitrogen content (Pyar and Peh, 2018). Papaya waste containing lower carbon but higher nitrogen than banana waste, so that the size of $§$-glucan particles were also smaller than the $\$$-glucan particles of banana waste (Saran et al., 2016). Meanwhile napa cabbage waste has the lowest carbon but highest nitrogen therefore it produced S-glucan with the smallest particle size (You et al., 2017).

\section{CONCLUSION}

Papaya waste chosen as the best fermentation medium in producing the number of §-glucan mass (19.094 g) with antioxidant activity of 20.71\%. The identification of §-glucan microstructur shown papaya waste fermentation medium resulted ß-glucan globular diameter of $533 \mu \mathrm{m}$.

\section{Acknowledgements}

Author would like to thank the Student Research Group, Vivi Fadila Sari, Isfari Dinika and Syarah Virgina who helped in the laboratory. The research funded by the Directorate of Research and Community Service, Directorate General of Research Strengthening and Development, Ministry of Research, Technology and Higher Education the Republic of Indonesia, through the scheme "Penelitian Dasar" and "Academic Leadership Grant” of Universitas Padjadjaran.

\section{REFERENCES}

AIMANIANDA, V., CLAVAUD, C., SIMENEL, C., FONTAINE, T., DELEPIERRE, M. and LATGÉ, J.-P. 2009. Cell Wall $\beta$-(1,6)-Glucan of Saccharomyces cerevisiae. The Journal of Biological Chemistry, 284(20): 13401-13412.

ANWAR, H., HUSSAIN, G. and MUSTAFA, I. 2018. Antioxidants from Natural Sources. In: Antioxidants in Foods and Its Applications. IntechOpen.

BALIA, R. L., KURNANI, T. B. A. and UTAMA, G. L. 2018. Selection of mozzarella cheese whey native yeasts with ethanol and glucose tolerance ability. International Journal on Advanced Science, Engineering and Information Technology, 8(4): 1091-1097.

BASHIR, K. M. I. and CHOI, J.-S. 2017. Clinical and Physiological Perspectives of $\beta$-Glucans: The Past, Present, and Future. International Journal of Molecular Sciences, 18(9): 1906.

BHATT, A. and PATEL, V. 2015. Antioxidant potential of banana: Study using simulated gastrointestinal model and conventional extraction. Indian Journal of Experimental Biology, 53(7): 457-461.

BROACH, J. R. 2012. Nutritional Control of Growth and Development in Yeast. Genetics, 192(1): 73-105.

CASTILLEJA, D. E. M., TAPIA, J. A. A., ARVIZUMEDRANO, S. M., ITURRIAGA, M. H., PENICHE, L. S. M. and R. A. M. 2017. Growth Kinetics for the Selection of Yeast Strains for Fermented Beverages. In: Yeast - Industrial Applications. Intechopen.

CENTRAL BUREAU OF STATISTICS. 2015. Horticultural Production Statistics of Vegetables and Fruits 2014-2015 [in Indonesian: Statistik Produksi Hortikultura Sayuran dan Buah 2014-2015]. Central Bureau of Statistics of West Java.

EIDE, D. J., CLARK, S., NAIR, T. M., GEHL, M., GRIBSKOV, M., GUERINOT, M. and HARPER, J. F. 2005. Characterization of the yeast ionome: a genome-wide analysis of nutrient mineral and trace element homeostasis in Saccharomyces cerevisiae. Genome Biology, 6(9): R77. 
EL KHOURY, D., CUDA, C., LUHOVYY, B. L. and ANDERSON, G. H. 2012. Beta Glucan: Health Benefits in Obesity and Metabolic Syndrome. Journal of Nutrition and Metabolism, Special Issue 2012: 851362.

GUNAM, I. B. W., WARTINI, N. M., ANGGRENI, A. A. M. D. and SUPARYANA, P. M. 2011. Delignifikasi Ampas Tebu dengan Larutan Natrium Hidroksida Sebelum Proses Sakarifikasi secara Enzimatis menggunakan Enzim Selulase Kasar dari Aspergillus niger FNU 6018. Teknologi Indonesia, 34: 24-32.

GUNATHILAKE, K. D. P. P., RANAWEERA, K. K. D. S. and RUPASINGHE, H. P. V. 2018. Effect of Different Cooking Methods on Polyphenols, Carotenoids and Antioxidant Activities of Selected Edible Leaves. Antioxidants, 7(9): 117.

KECHKAR, M., SAYED, W., CABROL, A., AZIZA, M., AHMED ZAID, T., AMRANE, A. and DJELAL, H. 2019. Isolation and Identification of Yeast Strains from Sugarcane Molasses, Dates and Figs for Ethanol Production Under Conditions Simulating Algal Hydrolysate. Brazilian Journal of Chemical Engineering, 36(1): 157-169.

KLIS, F. M., MOL, P., HELlingWERF, K. and BRUL, S. 2002. Dynamics of cell wall structure in Saccharomyces cerevisiae. FEMS Microbiology Reviews, 26(3): 239-256.

KOFUJI, K., AOKI, A., TSUBAKI, K., KONISHI, M., ISOBE, T. and MURATA, Y. 2012. Antioxidant Activity of $\beta$-Glucan. ISRN Pharmaceutics, 2012: 125864.

KUREK, M. A., WYRWISZ, J. and WIERZBICKA, A. 2016. Effect of $\beta$-glucan particle size on the properties of fortified wheat rolls. CyTA - Journal of Food, 14(1): 124-130.

LEENTJENS, J., QUINTIN, J., GERRETSEN, J., KOX, M., PICKKERS, P. and NETEA, M. G. 2014. The Effects of Orally Administered Beta-Glucan on Innate Immune Responses in Humans, a Randomized Open-Label Intervention Pilot-Study. PLOS ONE, 9(9): e108794.

LESAGE, G. and BUSSEY, H. 2006. Cell Wall Assembly in Saccharomyces cerevisiae. Microbiology and Molecular Biology Reviews, 70(2): 317-343.

MOHD AZHAR, S. H., ABDULLA, R., JAMBO, S. A., MARBAWI, H., GANSAU, J. A., MOHD FAIK, A. A. and RODRIGUES, K. F. 2017. Yeasts in sustainable bioethanol production: A review. Biochemistry and Biophysics Reports, 10: 52-61.

MU'NISA, A. 2012. Analisis Kadar Likopen dan Uji Aktivitas antioksidan pada Tomat Asal Sulawesi Selatan. Bionature, 13(1): 62-66.

NICKELS, J. D., ATKINSON, J., PAPP-SZABO, E., STANLEY, C., DIALLO, S. O., PERTICAROLI, S., BAYLIS, B., MAHON, P., EHLERS, G., KATSARAS, J. and DUTCHER, J. R. 2016. Structure and Hydration of HighlyBranched, Monodisperse Phytoglycogen Nanoparticles. Biomacromolecules, 17(3): 735-743.

NOVÁK, M., SYNYTSYA, A., GEDEON, O., SLEPIČKA, P., PROCHÁZKA, V., SYNYTSYA, A., BLAHOVEC, J., HEJLOVÁ, A. and ČOPÍKOVÁ, J. 2012. Yeast $\beta(1-3),(1-6)-d-g l u c a n$ films: Preparation and characterization of some structural and physical properties. Carbohydrate Polymers, 87(4): 2496-2504.

OGDEN, M., HOEFGEN, R., ROESSNER, U., PERSSON, S. and KHAN, G. A. 2018. Feeding the Walls: How Does Nutrient Availability Regulate Cell Wall Composition? International Journal of Molecular Sciences, 19(9): E2691.

ORLEAN, P. 2012. Architecture and Biosynthesis of the Saccharomyces cerevisiae Cell Wall. Genetics, 192(3): 775-818.

OSTERGAARD, S., OLSSON, L. and NIELSEN, J. 2000. Metabolic Engineering of Saccharomyces cerevisiae. Microbiology and Molecular Biology Reviews, 64(1): 34-50.

PENGKUMSRI, N., SIVAMARUTHI, B. S., SIRILUN, S., PEERAJAN, S., KESIKA, P., CHAIYASUT, K., CHAIYASUT, C., PENGKUMSRI, N., SIVAMARUTHI, B. S., SIRILUN, S., PEERAJAN, S., KESIKA, P., CHAIYASUT, K. and CHAIYASUT, C. 2017. Extraction of $\beta$-glucan from Saccharomyces cerevisiae: Comparison of different extraction methods and in vivo assessment of immunomodulatory effect in mice. Food Science and Technology, 37(1): 124-130.

PIOTROWSKA, M. and MASEK, A. 2015. Saccharomyces cerevisiae cell wall components as tools for ochratoxin a decontamination. Toxins, 7(4): 1151-1162.

PYAR, H. and PEH, K. K. 2018. Chemical Compositions of Banana Peels (Musa sapientum) Fruits cultivated in Malaysia using proximate analysis. Research Journal of Chemistry and Environment, 22(2): 108-113.

RACHMAWATI, Q. and HERUMURTI, W. 2015. Pengolahan Sampah Secara Pirolisis dengan Variasi Rasio Komposisi Sampah dan Jenis Plastik. Jurnal Teknik ITS, 4(1): D27-D29-D29.

RAHAR, S., SWAMI, G., NAGPAL, N., NAGPAL, M. A. and SINGH, G. S. 2011. Preparation, characterization, and biological properties of $\beta$-glucans. Journal of Advanced Pharmaceutical Technology \& Research, 2(2): 94.

RUIZ-HERRERA, J. and ORTIZ-CASTELLANOS, L. 2019. Cell wall glucans of fungi. A review. The Cell Surface, 5: 100022.

SALARI, R. and SALARI, R. 2017. Investigation of the Best Saccharomyces cerevisiae Growth Condition. Electronic Physician, 9(1): 3592-3597. 
SANCHEZ, S. and DEMAIN, A. L. 2008. Metabolic regulation and overproduction of primary metabolites. Microbial Biotechnology, 1(4): 283-319.

SARAN, P. L., SOLANKI, I. S. and CHOUDHARY, R. 2016. Papaya: Biology, Cultivation, Production and Uses. CRC Press.

SIDHU, J. S. and ZAFAR, T. A. 2018. Bioactive compounds in banana fruits and their health benefits. Food Quality and Safety, 2(4): 183-188.

STEWART, G. G. 2017. The Production of Secondary Metabolites with Flavour Potential during Brewing and Distilling Wort Fermentations. Fermentation, 3(4): 63.

TAURISANO, V., ANZELMO, G., POLI, A., NICOLAUS, B. and DI DONATO, P. 2014. Re-use of Agroindustrial Waste: Recovery of Valuable Compounds by Eco-friendly Techniques. International Journal of Performability Engineering, 10(4): 419-425.

TORRES-LEÓN, C., RAMÍREZ-GUZMAN, N., LONDOÑO-HERNANDEZ, L., MARTINEZ-MEDINA, G. A., DÍAZ-HERRERA, R., NAVARRO-MACIAS, V., ALVAREZ-PÉREZ, O. B., PICAZO, B., VILLARREALVÁZQUEZ, M., ASCACIO-VALDES, J. and AGUILAR, C. N. 2018. Food Waste and Byproducts: An Opportunity to Minimize Malnutrition and Hunger in Developing Countries. Frontiers in Sustainable Food Systems, 2: 52.

UPADHYAY, T. K., FATIMA, N., SHARMA, D., SARAVANAKUMAR, V. and SHARMA, R. 2017. Preparation and characterization of beta-glucan particles containing a payload of nanoembedded rifabutin for enhanced targeted delivery to macrophages. EXCLI Journal, 16: 210-228.

UTAMA, G. L., SIDABUTAR, F. E. E., FELINA, H., WIRA, D. W. and BALIA, R. L. 2019. The utilization of fruit and vegetable wastes for bioethanol production with the inoculation of indigenous yeasts consortium. Bulgarian Journal of Agricultural Science, 25(2): 264-270.

VARELAS, V., SOTIROPOULOU, E., KARAMBINI, X., LIOUNI, M. and NERANTZIS, E. T. 2017. Impact of Glucose Concentration and $\mathrm{NaCl}$ Osmotic Stress on Yeast Cell Wall $\beta$-d-Glucan Formation during Anaerobic Fermentation Process. Fermentation, 3(3): 44.

VARZAKAS, T., ZAKYNTHINOS, G. and VERPOORT, F. 2016. Plant Food Residues as a Source of Nutraceuticals and Functional Foods. Foods, 5(4): E88.

VERGHESE, M., SUNKARA, R., SALLA, S. and WALKER, L. T. 2016. Antioxidant and Apoptotic Activity of Papaya Peel Extracts in HepG2 Cells. Food and Nutrition Sciences, 7(6): 720-726.

VERMEERSCH, L., PEREZ-SAMPER, G., CERULUS, B., JARIANI, A., GALLONE, B., VOORDECKERS, K., STEENSELS, J. and VERSTREPEN, K. J. 2019. On the duration of the microbial lag phase. Current Genetics, 65(3): 721-727.

VETVICKA, V., VANNUCCI, L., SIMA, P. and RICHTER, J. 2019. Beta Glucan: Supplement or Drug? From Laboratory to Clinical Trials. Molecules, 24(7): E1251.

WALKER, G. and STEWART, G. 2016. Saccharomyces cerevisiae in the Production of Fermented Beverages. Beverages, 2(4): 30.

WANG, Q., SHENG, X., SHI, A., HU, H., YANG, Y., LIU, L., FEI, L. and LIU, H. 2017. $\beta$-Glucans: Relationships between Modification, Conformation and Functional Activities. Molecules (Basel, Switzerland), 22(2): E257.

WILLAERT, R. G. 2019. Yeast Biotechnology 2.0. MDPI.

WU, C. Y., LIANG, Z. C., LU, C. P. and WU, S. H. 2008. Effect of Carbon and Nitrogen Sources on The Production and Carbohydrate Composition of Exopolysaccharide by Submerged Culture of Pleurotus citrinopileatu. Journal of Food and Drug Analysis, 16(2): 61-67.

XU, Z. 2012. Important Antioxidant Phytochemicals in Agricultural Food Products. In: Analysis of Antioxidant-Rich Phytochemicals. John Wiley \& Sons, pp. 1-24.

YODHA, A. H. 2018. Sustainable development in Indonesia: holistic assessments and pathways. Cambridge, United States: Massachusetts Institute of Technology.

YOSHIMI, A., MIYAZAWA, K. and ABE, K. 2017. Function and Biosynthesis of Cell Wall a-1,3-Glucan in Fungi. Journal of Fungi, 3(4): E63.

YOU, S.-Y., YANG, J.-S., KIM, S. H. and HWANG, I. M. 2017. Changes in the Physicochemical Quality Characteristics of Cabbage Kimchi with respect to Storage Conditions. Journal of Food Quality, 2017: 9562981. 